\title{
Rice Farming with Application of Integrated Pest Management (IPM): Analysis of Social and Economic Sustainability (Case Study in Besur Village, Lamongan District)
}

\author{
Aminudin Afandhi* \\ Plant Protection Department, Agriculture Faculty, Brawijaya University, Veteran Street, Malang 65145, \\ East Java, Indonesia
}

Received: 2 March 2020; Revised: 29 June 2020; Accepted: 17 July 2020

\begin{abstract}
Environmental degradation and pest attack against rice plants obstruct efforts to increase rice production in Indonesia. one attempt to overcome the problem by applying rice farm with Integrated Pest Management (IPM). This study aimed to examine the sensitivity level of social and economic attributes that were sustainable in rice farming with IPM application. This research was conducted in September and October 2018 Village Besur, Lamongan District. The data used in this research were secondary and primary data. Secondary data obtained from literature studies while primary data obtained by observation and survey of farmers and stakeholders. Furthermore, the data were analyzed with RAP-IPM (Rapid Appraisal for Integrated Pest Management) approach by applying the techniques of MDS (Multidimensional Scaling) using software Rapfish (Rapid Assessment Techniques for Fisheries). The results showed that the sensitivity level of social and economic attributes was sustainable in rice farming with the application of IPM in Besur Village. This implies that the application of IPM is the right solution to improve the sustainability of rice farming in Indonesia.
\end{abstract}

Keywords: IPM; rice; social; economy; sustainability

\section{How to Cite:}

Afandhi, A. (2020). Rice Farming with Application of Integrated Pest Management ( IPM ): Analysis of Social and Economic Sustainability ( Case Study in Besur Village , Lamongan District ). Habitat, 31(2), 109-114. https://doi.org/10.21776/ub.habitat.2020.031.2.13

\section{Introduction}

As the basic needs of foods for Indonesian, rice becomes a special concern for researchers (Indriyani, 2004). In Indonesia, paddy or rice is an important indicator of food conditions for an area. Because of the level of rice consumption reaches $132.98 \mathrm{~kg} / \mathrm{capita} /$ year, the increasing of rice production is currently a top priority in fulfilling the food needs of the population in Indonesia (Agricultural Data and Information System Center, 2015). The increasing population will certainly increase the demand for rice and it will determine the food security status in Indonesia. The last few decades of agricultural intensification were a solution to meet the food needs. Organic farming, to improve the sustainability of rice farming in order to increase rice productivity in Soreang District, Bandung Regency, was a technological implication from the research of

${ }^{*}$ Correspondence Author

E-mail : aaf_fp@ub.ac.id
Dzikrillaha, G.F., Syaiful Anwar, S., Sutjahjo, S.S., (2017). The high use of chemicals in agricultural activities has been proven to have a negative impact on agricultural sustainability, the natural balance will be disrupted by the emergence of pests and pathogens that are resistant (Carvalho, 2006). FAO (2018) further explained that $69 \%$ of the land in Indonesia was damaged and the crop productivity decreased caused by high use of chemicals. The results of research conducted by Suhartono, Kartini, \& Subagio, (2018) showed that most of the water flow used for agriculture in Indonesia contained chemicals, especially in the use of pesticides. On the other hand, environmental damage due to agricultural intensification also had a negative impact on the sustainability of socioeconomic conditions, community welfare (Carvalho, 2006). One of the efforts to overcome these problems was the cultivation of rice by applying IPM (Integrated Pest Control). Rice farming with the application of IPM in Indonesia has been developed. An area that 
considered successful in the cultivation of rice by applying IPM was Lamongan Regency.

The social and economic dimensions were 60.90 and 51.39, respectively, including the quite sustainable criteria for IPM-based vegetable farming (Sudiono et al., 2017). The ecological dimension with biological control attributes showed that IPM rice farming was sustainable (Afandhi, Al Aluf, \& Prasetya, 2019). Although the application of IPM-based rice farming has been seen as able to maintain agricultural sustainability, the results of previous studies was only based on the ecological dimension. So, the questions about the sustainability of the IPM application in the rice farming in terms of social and economic dimensions would appear. To answer this question, this study aimed to examine the level of sensitivity of social and economic attributes that were sustainable in rice farming by applying IPM in Besur Village, Sekaran, Lamongan.

\section{Research Methodology}

\subsection{Time and Location}

This research conducted in Besur Village, Sekaran District, Lamongan Regency. Site selection was done purposively (deliberately) with the consideration that the location has implemented IPM-paddy rice farming. Furthermore, this research carried out in September to October 2018.

\subsection{Data of the Research}

The sample of the research were 50 farmers who applied IPM-paddy farming. Two types of data used in this study included secondary and primary data. Furthermore, the primary data used from this research obtained directly by observation and survey at the research location. The survey was conducted with a questionnaire tool. Farmers and policy makers became a source of information to obtain data and information needs related to the management of IPM rice fields at the research location. Secondary data was collected through literature studies from several published scientific papers related to this research.

\subsection{Multidimensional Scaling (MDS) Data Analysis}

Analysis of IPM-based rice farming sustainability was carried out using the RAP-IPM (Rapid Appraisal for Integrated Pest Management) approach by applying MDS
(Multidimensional Scaling) techniques using Rapfish (Rapid Assessment Techniques for Fisheries) software to determine the index and sustainability status. A modified RAP-IPM approach from Rapfish (Rapid Assessment Techniques for Fisheries) (Sudiono, et al., 2017). The MDS method was one of the statistical analysis techniques that transformed each dimension as well as multidimensional in the sustainability dimensions of IPM rice farming. Some stages in the RAP-IPM approach include:

1) Determination of the IPM rice farming attributes

2) Rating of each attribute (scoring) on the ordinal scale. Rating of each attribute on the ordinal scale was based on the sustainability criteria of each dimension. Giving ordinal scores in the range $0-3$.

3) Determination of the ordination and value by conducting MDS analysis;

4) Rotating to determine the design of the IPM paddy farming sustainability in bad and good ordination in RAP analysis using Microsoft Excel. With the rotation process, the position of the point could be visualized on the horizontal axis with a sustainability index value given a score of $0 \%$ (bad) and $100 \%$ (good). If the sustainability index value was greater or equal to $50 \%$, then it was said to be sustainable and not sustainable if the index value was less than $50 \%$.

5) Assessing sensitive attributes that affected the sustainability of IPM-based rice farming using leverage analysis.

6) Assessing the effect of errors in calculations using Monte Carlo analysis (Dubrovsky, 2004).

In the MDS approach there are effects of errors that could be caused by various things such as errors in making scores, variations in scores due to differences in opinions, repetitive MDS analysis processes, data entry errors or missing data (Kavanagh \& Pitcher, 2004). So, stress value and the coefficient of determination (R2) in the RAP analysis to prove that the MDS analysis performed had low accuracy and error effect. Stress values on all dimensions and averages had values smaller than 0.25 , ranging from 0.12 to 0.18 . If the stress value got smaller, the data used got better. It meant that the effect of the error on rating an attribute was very small. While the coefficient of determination (R2) for each dimension and average was quite high and close to number 1 , which ranged from 0.96 to 0.98 . This 
showed that there was a close correlation between the attributes in an analyzed dimension. The quality of the analysis results was better if the coefficient of determination (R2) was greater (close to 1) and the stress value could be accepted if the value $<0.25(25 \%)$ (Kavanagh \& Pitcher, 2004).

\section{Results and Discussions}

\subsection{Sensitive Attributes in Social Dimensions}

The sustainability status of the social dimension was generated based on the assessment of 10 sustainability attributes. The attributes of sustainability included: (1) farmers' perceptions and satisfaction, (2) alternative business besides farming, (3) frequency of conflict, (4) frequency of counseling, (5) participation of farmer group members, (6) farmer motivation farming, (7) family participation, (8) farmer knowledge, (9) community views and (10) farming experience.
Attributes that were sensitive to the social dimension based on the results of leverage analysis referred to the value of RMS (Root Mean Square).

The determination of sensitive attributes on the social dimension was determined by selecting attributes that had an RMS value change more than half of the value scale on the $\mathrm{X}$ axis and based on the order of priority in the results of leverage analysis by looking at the shape of the RMS ordination change on the $\mathrm{X}$ axis. The greater the leverage index, the most sensitive compared to other attributes (Hikmah, Yulisti, \& Nasution, 2017). Based on the results of leverage analysis, the social dimension showed that of the 10 attributes analyzed, there were 2 sensitive attributes that affected IPM paddy farming, namely family participation in IPM paddy farming and the experience of farmers in paddy farming (Figure 1).

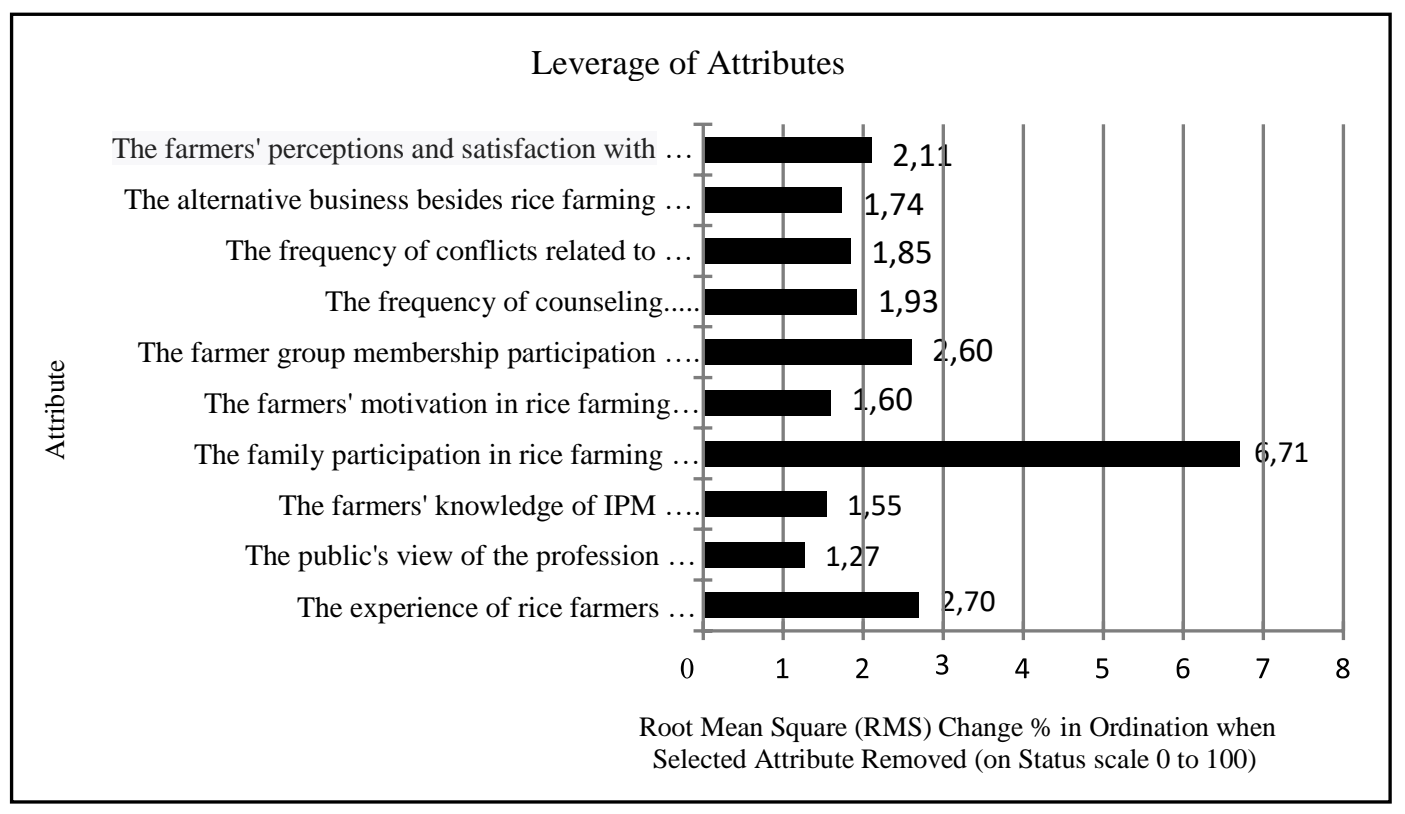

Figure 1. Sensitive attributes that affected the social dimension sustainability of wetland rice farming by applying IPM

Participation is involvement in an activity by an individual or group in community member (Yani \& Farida, 2014). Based on the questionnaire, the family members were very supportive in IPM rice farming. This was because the income derived from the results of IPM rice farming was higher than conventional rice farming. In addition, the expenses for purchasing production facilities were not too expensive and almost all the people of Desa Besur depended on the agricultural sector. Family members could enjoy the results of IPM rice farming. (Slamet,
2003) stated that participation was divided into 5 , namely (1) giving input, receiving rewards for the input, and enjoying the results; (2) providing input and enjoying the results; (3) providing input and giving rewards without directly enjoying the results; (4) utilizing results without providing input; and (5) providing input without receiving rewards and not enjoying results (Slamet, 2003).

The level of farming experience could affect the level of ability in farming and increase the skills of farmers (Mardani, Nur, \& Satriawan, 2017). The farming experience level of farmers in 
Besur Village averages 16-30 years. This condition affected the productivity and success in farming. The length of farming experience was an indicator in supporting the success of farming. Farmers who had longer farming experience were able to plan farming well, because they had understood all aspects of farming.

\subsection{Sensitive Attributes in Economic Dimensions}

The sustainability status of the economic dimension generated based on an assessment of 10 sustainability attributes. The attributes of sustainability included: (1) profits from farmers, (2) market opportunities, (3) selling price of output (rice), (4) selling price of grain production at harvest, (5) price of input production, ( 6) biological control costs, (7) pest control labor costs, (8) price of chemical pesticides, (9) price of biological pesticides and (10) pest control efforts. Attributes that were sensitive to the economic dimension based on the results of leverage analysis referred to the value of RMS (Root Mean Square).

The determination of sensitive attributes on the economic dimension was determined by selecting attributes that had an RMS value change of more than half of the value scale on the $\mathrm{X}$ axis and based on the order of priority in the results of leverage analysis by looking at the shape of the RMS ordination change on the $\mathrm{X}$ axis. The greater the leverage index the most sensitive compared to other attributes (Hikmah et al., 2011). Based on the results of the leverage analysis of the economic dimension, it showed that out of 10 attributes analyzed there were 4 sensitive attributes that affected IPM paddy farming. The four attributes were sensitive to the sustainability of the economic dimension, including: (1) selling price of output (rice), (2) input prices, (3) labor cost of pest control and (4) price of chemical pesticides (Figure 2).

The price of grain and rice were one of the production variables which was determined by external factors of the farmer. Output prices were determined by market mechanisms prevailing at the farm level (Kavanagh \& Pitcher, 2004). Based on research data, the price of grain per sack of Rp5,000 with the system of cutting down to middlemen while the selling price of rice was $\mathrm{Rp} 11,000 / \mathrm{kg}$. But when compared to inorganic rice, the price of organic rice was more expensive and the price received by farmers was also greater. The rice sold by Besur Village farmers had a good quality because of its savory taste and fluffier texture. Some parameters that affected rice quality included taste, color, aroma, composition contained, pithy and clean, efficacy/benefits and rice quality certification (Dewi, Sudarta, \& Ustriyana, 2013).

Production facilities (saprodi) used by respondent farmers in IPM rice farming included seeds, organic and inorganic fertilizers, PGPR (Plant Growth Promoting Rhizobacteria), decomposers and biological pesticides. Based on respondent farmer data, the price of production input for IPM rice farming was not too expensive. Although farmers also used inorganic fertilizers, the costs were not too expensive. This was because the price of production input for IPM-based rice farming was cheaper than conventional rice farming. IPM-based rice farming provided large benefits to farmers because the price of production facilities incurred by farmers was smaller and the benefits obtained were greater. The difference in the total cost of rice farming in both SL-PTT and non-SL-PTT farmers could be caused by one of them being differences in production facilities (Suharyanto, 2015). The profitability of SL-PTT farmers was higher than non-SL-PTT farmers, this was because the input price was low and the price of output received was relatively higher (Suharyanto, 2015). In rice farming, almost all parts of the production process required labor. The used of IPM application could reduce the labor costs in controlling pests. To minimize expenditure, the farmers in Besur employ their families in controlling the pests. Farmers who generally had limited capital would implement IPM-based rice farming to reduce labor expenditure (Suhartono et al., 2018; Suharyanto, 2015).

In general, the cost structure of rice farming between SL-PTT and non-SL-PTT farmers was different in terms of pesticide used. Pesticide costs incurred by SL-PTT farmers were lower than nonSL-PTT farmers. This related to one of the components in PTT, namely the application of the IPM concept in OMO regulation while the use of chemical pesticides was in accordance with the threshold (Suharyanto, 2015). Farmers in Besur Village had started not using chemical pesticides because the price of pesticides was more expensive than biological pesticides. In addition, the application of IPM in rice farming could reduce the use of chemical pesticides in controlling pests that increased the production costs. From an educational standpoint, the application of IPM must be able to increase 
farmers' knowledge in making decisions about the use of chemical pesticides on the basis of profit and loss considerations (Irham \& Mariyono, 2001).

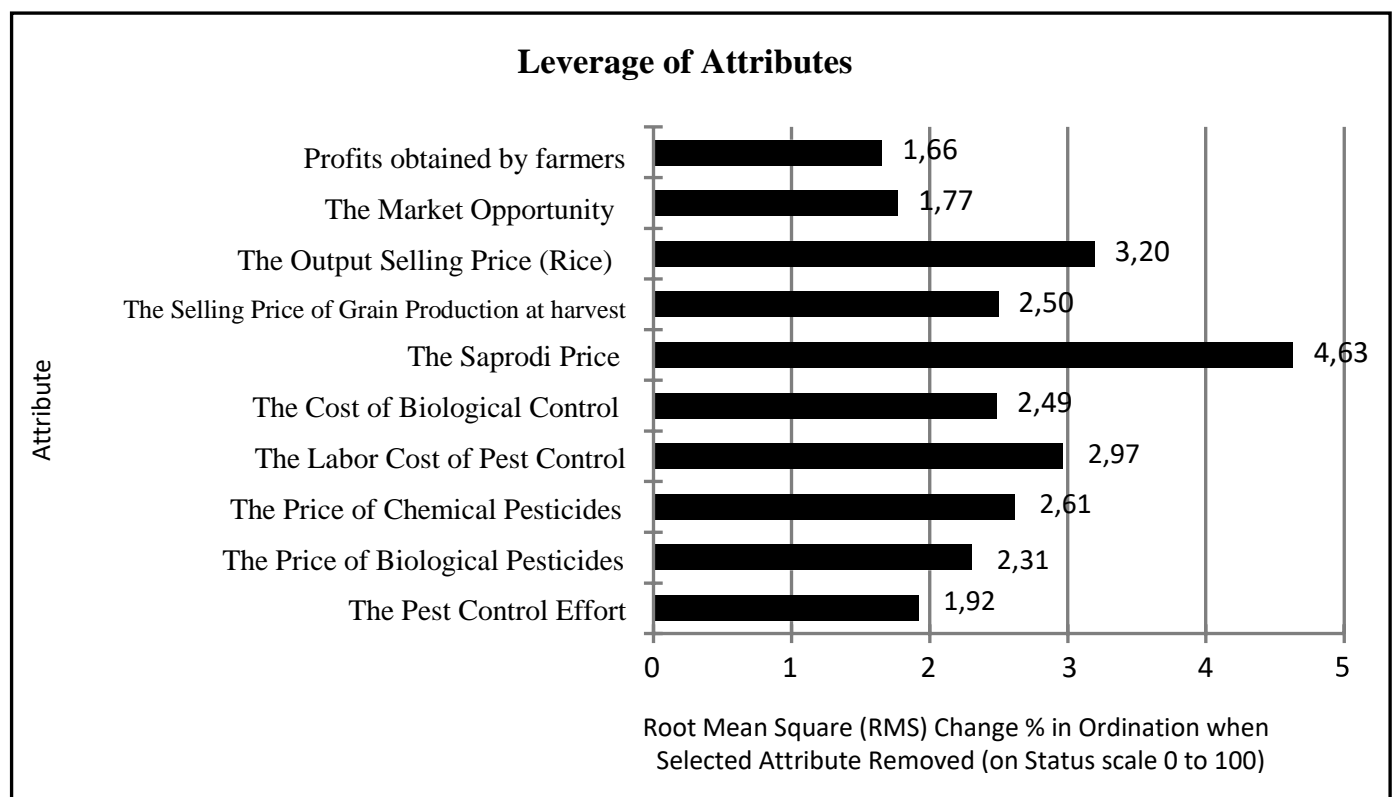

Figure 2. Sensitive attributes that affected the economic dimensions sustainability of rice farming by applying IPM

\section{Conclusion}

To sum up, the social dimensions shows that out of the 10 attributes analyzed there are 2 sensitive attributes that affect IPM rice farming, namely family participation in IPM rice farming and the experience of rice farmers. Furthermore, the economic dimension shows that out of the 10 attributes analyzed there are 4 sensitive attributes that affect IPM paddy farming. Four attributes are sensitive to the sustainability of the economic dimension, including: (1) the selling price of output (rice), (2) the price of inputs, (3) the labor costs of pest control and (4) the price of chemical pesticides.

\section{References}

Afandhi, A., Al Aluf, W., \& Prasetya, B. (2019). Evaluation of the Lowland Rice Sustainability Based on the Dimensions of Biological Control in Besur Village, Lamongan District. The Indonesian Green Technology Journal, 8(1).

Carvalho, F. P. (2006). Agriculture, pesticides, food security and food safety. Environmental science \& policy, 9(7-8), 685-692.

Dewi, I. A. R. P., Sudarta, W., \& Ustriyana, I. N. G. (2013). Persepsi konsumen terhadap beras organik dan anorganik di toko Satvika Boga Sanur Denpasar. Jurnal Agribisnis dan Agrowisata (Journal of Agribusiness and Agritourism).

Dubrovsky, V. (2004). Toward system principles: general system theory and the alternative approach. Systems Research and Behavioral Science: The Official Journal of the International Federation for Systems Research, 21(2), 109-122.

Hikmah, H., Yulisti, M., \& Nasution, Z. (2017). Analisis Indeks Dan Status Keberlanjutan Peran Serta Wanita Dalam Pengembangan Usaha Pengolahan Hasil Perikanan. Jurnal Sosial Ekonomi Kelautan Dan Perikanan, 6(1), 103-114.

Indriyani, C. (2004). Peranan sektor padi dalam pembangunan wilayah di kabupaten Kudus (dengan pendekatan analisis input-output). https://digilib.uns.ac.id/dokumen/

Irham, I., \& Mariyono, J. (2001). Perubahan Cara Pengambilan Keputusan Oleh Petani Pengendalian Hama Terpadu (Pht) Dalam Menggunakan Pestisida Kimia Pada Padi (the Change of Chemical Pesticides Use Decision Making in Rice by Intergrated Farms). Jurnal Manusia dan Lingkungan, 8(2), 91-97. 
Kavanagh, P., \& Pitcher, T. J. (2004). Implementing Microsoft Excel software for Rapfish: a technique for the rapid appraisal of fisheries status.

Mardani, M., Nur, T., \& Satriawan, H. (2017). Analisis Usaha Tani Tanaman Pangan Jagung di Kecamatan Juli Kabupaten Bireuen. Jurnal Sains Pertanian, 1(3).

Slamet, M. (2003). Membentuk pola perilaku manusia pembangunan: Bogor: IPB Press.

Suhartono, S., Kartini, A., \& Subagio, H. W. (2018). Pesticide exposure and thyroid function in elementary school children living in an agricultural area, Brebes district, Indonesia. The international journal of occupational and environmental medicine, 9(3), 137.

Suharyanto, S. (2015). Efisiensi ekonomi relatif usahatani padi sawah dengan pendekatan fungsi keuntungan pada program sekolah lapang-pengelolaan tanaman terpadu (SLPTT) di Provinsi Bali. Informatika Pertanian, 24(1), 59-66.

Sudiono, Sutjahyo, S. H., Wijayanto, N., Hidayat, P., \& Kurniawan, R. (2018). Analisis Berkelanjutan Usahatani Tanaman Sayuran Berbasis Pengendalian Hama Terpadu di Kabupaten Tanggamus Provinsi Lampung. J. Hort. Vol. 27 No. 2, Desember 2017 : 297-310

Yani, D. E., \& Farida, I. (2014). Pemodelan Tingkat Partisipasi Wanita Tani Dalam Pendapatan Rumah Tangga Dan Pengaruhnya Terhadap Konsumsi KeluARGA.

http://repository.ut.ac.id/5431/

Dzikrillaha ,G.F., Syaiful Anwar, S., Sutjahjo, S.S., 2017. Analisis Keberlanjutan Usahatani Padi Sawah Di Kecamatan Soreang Kabupaten Bandung. Jurnal Pengelolaan Sumberdaya Alam dan Lingkungan Vol. 7 No. 2 (Agustus 2017): 107-113. 